\title{
COMPRESSIVE STRENGTH OF RESIN-MODIFIED GLASS IONOMER RESTORATIVE MATERIAL: EFFECT OF P/L RATIO AND STORAGE TIME
}

\author{
RESISTÊNCIA À COMPRESSÃO DE IONÔMEROS DE VIDRO MODIFICADOS POR RESINA: \\ EFEITO DA RELAÇÃO P/L E TEMPOS DE ARMAZENAGEM
}

Mônica ARATANI ${ }^{1}$, Antônio Carlos PEREIRA², Lourenço CORRER-SOBRINHO ${ }^{3}$, Mário Alexandre Coelho SINHORETI ${ }^{4}$, Simonides CONSANI ${ }^{5}$

1- DDS, MSc, Graduate Student (Master degree), Department of Restorative Dentistry, State University of Campinas, Brazil.

2- DDS, MSC, PhD, Titular Professor, Department of Community Dentistry, State University of Campinas, Brazil.

3- DDS, MSc, PhD, Titular Professor, Department of Restorative Dentistry, State University of Campinas, Brazil.

4- DDS, MSc, PhD, Associate Professor, Department of Restorative Dentistry, State University of Campinas, Brazil.

5- DDS, PhD, Titular Professor, Department of Restorative Dentistry, State University of Campinas, Brazil.

Corresponding address: Lourenço Correr Sobrinho - Av. Limeira 901, Bairro Areião - 13414-903 Piracicaba - SP, Brazil sobrinho@fop.unicamp.br - Phone: 5519 3412-5348 - Fax: 5519 3412-5250

Received: February 1, 2005 - Modification: March 24, 2005 - Accepted: May 25, 2005

\begin{abstract}
$T_{\text {ra }}$ The aim of this study was to evaluate the compressive strength of resin-modified glass ionomer cement Fuji II LC and Vitremer, in powder/liquid ratios of 1:1, 1:2 and 1:3, at three periods (24 hours, 7 and 28 days) of storage in distilled water at $37^{\circ} \mathrm{C}$. For each material, P/L ratio and storage time, 5 cylindrical specimens were prepared, with $4 \mathrm{~mm}$ diameter and $6 \mathrm{~mm}$ height, in silicon moulds. Specimens were light-cured for 40 seconds at each extremity, removed from the moulds and laterally light-cured (perpendicular to long axis) for 40 seconds, protected as recommended by the manufacturers and immersed for the time tested. The specimens were submitted to compressive strength testing in an Instron machine at a crosshead speed of $1.0 \mathrm{~mm} / \mathrm{min}$ until failure. Data were submitted to ANOVA and Tukey's test (5\%), and showed that the compressive strength of resin-modified glass ionomer cement was reduced when $\mathrm{P} / \mathrm{L}$ ratio was reduced and that the storage in water had little influence on compressive strength.

Uniterms: Glass ionomer cements; Dental materials; Dental caries; Compressive strength.
\end{abstract}

\section{RESUMO}

objetivo deste estudo foi avaliar a resistência à compressão dos cimentos de ionômero de vidro modificados por resina Vitremer e Fuji II LC, nas relações pó/líquido 1:1, 1:2 e 1:3, por três períodos de armazenagem (24 horas, 7 e 28 dias) em água destilada a $37{ }^{\circ} \mathrm{C}$. Para cada material, relação pó/líquido e tempo de armazenagem, cinco corpos-de-prova cilíndricos foram preparados com $4 \mathrm{~mm}$ de diâmetro por $6 \mathrm{~mm}$ de altura, em moldes de silicone. Os corpos-de-prova foram fotoativados por 40 segundos, em cada extremidade, removidos dos moldes, fotoativado lateralmente (perpendicular ao longo eixo) por 40 segundos, protegidos conforme as instruções dos fabricantes e imersos pelo tempo de teste. Os corpos-de-prova foram submetidos à compressão em uma Instron, à velocidade de $1,0 \mathrm{~mm} / \mathrm{min}$ até a falha. Os dados foram submetidos à análise de variância e ao teste de Tukey (5\%), e mostraram que a resistência à compressão do cimento de ionômero de vidro modificado por resina foi reduzida quando a relação P/L foi diminuída e a armazenagem em água destilada teve pouca influência na resistência à compressão.

Unitermos: Cimentos de ionômeros de vidro; Materiais dentários; Cárie dentária; Resistência à compressão. 


\section{INTRODUCTION}

Mechanical properties of glass ionomer cements have been investigated since their development, and concerns have remained even after the development of resin-modified versions. Information regarding durations and conditions of storage have allowed the formulation of hypotheses to investigate the role of acid-base and polymerization reactions, and their effect on mechanical strength and consequently on clinical behavior ${ }^{1,7,8}$.

Retention of glass ionomer cement pit and fissure sealants seems to be related to adhesion to enamel and the mechanical strength of the material ${ }^{24,26}$, which is lower when fluoride release is higher ${ }^{29}$. Clinical trials use commercially available resin-modified glass ionomer cements for restorative purposes in pit and fissure sealants, because they demonstrate greater strength immediate after lightcuring and their application is easier, with a longer working time and reduces the early sensitivity to water contamination $^{18}$. In regard to changing the $P / L$ ratio, the physical properties of conventional glass ionomers and resin-modified glass ionomer cements decrease depending on the reduction of powder volume ${ }^{17}$. The powder/liquid ratio is reduced to improve flow properties ${ }^{10,14,19,20}$ but also results in higher solubility ${ }^{23}$, compromising the durability of the fragments that remain in the fissure, responsible for protection of the occlusal surface ${ }^{16}$. For this reason, improvement of retention rates is desirable to avoid caries development on occlusal surfaces for extended periods.

So, any $\mathrm{P} / \mathrm{L}$ alteration will result in a resin-modified glass ionomer cement with worse mechanical properties. Consequently, lower compressive strength showed by $\mathrm{P} / \mathrm{L}$ ratios reduces the clinical long-term performance, mainly in the wear strength and solubility. The aim of this study was to evaluate the compressive strength of two resin-modified glass ionomer cements (Vitremer and Fuji II LC) in $P / L$ ratios of 1:1, $1: 2$ and $1: 3$ after 24 hours, 7 and 28 days of storage in distilled water at $37^{\circ} \mathrm{C}$.

\section{MATERIALAND METHODS}

Two resin-modified glass ionomers, Fuji II LC (GC corporation, Tokyo, Japan) and Vitremer (3M Dental Products, St. Paul, MN, USA), were used. The $P / L$ ratios employed were 1:1, 1:2 and 1:3; signifying 2.5, 1.25 and 0.83mg of powder for each mg of liquid for Vitremer, and 3.2, 1.6 and $1.06 \mathrm{mg}$ of powder for each mg of liquid for Fuji II LC. Liquid was weighed on impermeable paper and the corresponding amount of powder was calculated and immediately added by weight.

The resin-modified glass ionomer cements were mixed by agglutination of powder to liquid in two portions and placed with Centrix syringe (Centrix Inc., Shelton, USA) in a silicon mould (4mm in diameter and $6 \mathrm{~mm}$ in high) ${ }^{12,21}$ between two glass plates. Then they were exposed to a light source (XL 2500 - 3M Dental Products, St. Paul, MN, USA), with intensity of $750 \mathrm{~mW} / \mathrm{cm}^{2}$ for 40 seconds per side, totalizing 80 seconds. The specimens were removed from the moulds and submitted to an additional lateral lightcuring for 40 seconds. After setting, the cements were protected with their respective coatings (finishing gloss Vitremer and Fuji Coat LC - Fuji II LC) and additional 20 seconds of irradiation were applied on each side, according to the manufacturer's instructions. Afterwards, the specimens were kept in distilled water for 24 hours, 7 and 28 days at $37^{\circ} \mathrm{C}$. Ninety specimens were prepared, five for each material, $P / L$ ratio and storage time.

After storage, the surfaces of each specimen were ground flat and polished using 600 and 1200 grit sandpaper (Norton SA, São Paulo, Brazil) on an automated rotary grinder (Metalserv-Rotary Pregrinder, London, England) under gently running tap water and dried with absorbent paper. Afterwards, the specimens were submitted to compressive strength in an Instron machine (4411 - Canton, Mass, USA) at a crosshead speed of $1.0 \mathrm{~mm} /$ minute until failure occurred. All statistical analyses were conducted at a significance level of $\mathrm{p}<0.05$. Data were checked for test distribution which revealed normal test distribution for all groups. Three-way analysis of variance (ANOVA) and Tukey's test were performed on fracture data for each storage time and each $P / L$ ratio for each material.

\section{RESULTS}

Table 1 shows the mean compressive strengths for Vitremer in 1:1, 1:2 and 1:3 P/L ratios after 24 hours, 7 and 28 days of storage time. The compressive strength values for 1:1 ratios were significantly higher than those obtained for $1: 2$ and $1: 3$ ratios $(\mathrm{p}<0.05)$ for three storage times; and the values for 1:2 ratios were significantly higher than those for

TABLE 1- Mean compressive strength (MPa) of Vitremer for three different $P / L$ ratios and storage times

$$
2.5(1: 1)
$$

24 hours

7 days

28 days
$218.46 \pm 7.72 \quad A, a$

$198.41 \pm 23.58 \quad$ A, a

$196.24 \pm 27.20 \quad$ A, a
$1.25(1: 2)$

$130.70 \pm 8.63 \quad \mathrm{~B}, \mathrm{a}$

$142.74 \pm 9.34 \quad \mathrm{~B}, \mathrm{a}$

$140.28 \pm 18.29 \quad B, a$
$0.83(1: 3)$

$98.79 \pm 4.88 \quad \mathrm{C}, \mathrm{a}$

$108.79 \pm 9.95 \quad \mathrm{C}, \mathrm{a}$

$117.36 \pm 8.31 \quad \mathrm{C}, \mathrm{a}$

Means followed by the same small case letters in the column and capital letters in the row indicate no statistical difference at the 95\% confidence level (Tukey's test, $\mathrm{p}>0.05$ ). 
$1: 3$ ratios $(\mathrm{p}<0.05)$. No statistically significant difference in compressive strength was observed between the storage times for all $\mathrm{P} / \mathrm{L}$ ratios studied ( $\mathrm{p}>0.05$ ).

Table 2 shows the mean compressive strength for Fuji II LC in 1:1, 1:2 and 1:3 P/L ratios after 24 hours, 7 and 28 days of storage time. The compressive strength values for $1: 1$ ratios were significantly higher than $1: 2$ and $1: 3$ ratios for all storage times $(\mathrm{p}<0.05)$. The values for $1: 2$ ratios were significantly higher than for 1:3 ratios for the storage times of 24 hours and 7 days $(\mathrm{p}<0.05)$, but no difference was found for 28 days ( $p>0.05$ ). No statistically significant difference in compressive strength was observed when Fuji II LC was tested at $1: 1$ and $1: 2 P / L$ ratios at any storage time $(\mathrm{p}>0.05)$. For 1:3 $P / L$ ratios the compressive strength values for the storage time of 28 days were significantly higher than for 24 hours and 7 days $(\mathrm{p}<0.05)$.

\section{DISCUSSION}

The strength values of glass ionomer cements shown in the literature are difficult to be compared due to the great variability in test conditions results and available material. These differences can be determined by composition, manufacturing process, size of the powder particles, type, concentration and molecular weight of liquid, and powderliquid ratio ${ }^{6,22}$. Resin/glass ionomer ratio in resin-modified glass ionomer also determines physical and mechanical properties and their degradation ${ }^{17}$.

This study found no significant difference between mean values of compressive strength of Vitremer and Fuji II LC, after storage in water for 24 hours, 7 days and 28 days. However, conditions at the time of the test can interfere in results, and some conflict exists in the literature, demonstrating the compressive strength of Vitremer to be superior to Fuji II LC ${ }^{3}$ or vice versa ${ }^{28}$. No conclusive results can be found in the literature and variations on specimen dimensions, storage medium time and cross-head speeds of tests are described.

Data from literature for 1:1 $\mathrm{P} / \mathrm{L}$ ratio are close to those found in this work. So, compressive strength values found by Kerby, et al. ${ }^{13}$ (1997) for Vitremer (208.4 $\pm 12.3 \mathrm{MPa}$ at 1 day and 254.6 $\pm 17.4 \mathrm{MPa}$ at 7 days of water storage), showed similar values when similar conditions were applied. The same occurred with Fuji II LC, for which $214 \pm 21 \mathrm{MPa}^{8}$ and 210. $0 \pm 12.1 \mathrm{MPa}$ were observed after 1 day of storage and
$206.0 \pm 13.9 \mathrm{MPa}$ after 7 days $^{13}$. Higher values were found by Xie, et al. ${ }^{27}$ (2000) respectively, $265.3 \pm 7.5 \mathrm{MPa}$ for Vitremer and 306.2 $\pm 6.8 \mathrm{MPa}$ for Fuji II LC after 1 week of storage, but specimens had dimensions of $8 \mathrm{~mm}$ by $4 \mathrm{~mm}$. Changes in specimens dimensions ( $3 \mathrm{~mm} \mathrm{X} 4 \mathrm{~mm}$ ) can also explain lower compressive strength found by Yap, et al. ${ }^{29}$ (2001) for Fuji II LC 147.11 $\pm 0.74 \mathrm{MPa}$ after 1 day, $149.37 \pm 0.75 \mathrm{MPa}$ after 1 week and $148.06 \pm 0.99 \mathrm{MPa}$ after 1 month of water storage. Specimens dried at the moment of testing, after water storage, demonstrate higher strengths than those kept in a wet environment ${ }^{8}$.

Alterations in viscosity are frequent ${ }^{4}$ and can interfere severely with the strength of thess cements ${ }^{17}$. When $P / L$ ratio is reduced, there is a decrease in the ion release process and, consequently, the cross links present lower strengths ${ }^{17}$ which can be reduced more rapidly ${ }^{1}$. However, at high P/L ratios, unreacted particles can act as stress concentration points and also reduce strength ${ }^{29}$. Since alterations on the $\mathrm{P} / \mathrm{L}$ ratio of RMGIC have the objective of improving flow properties for use as a pit and fissure sealant, the relation between compressive strength properties and its significance on RMGIC used as a sealant should be discussed.

Water storage can result in a decrease in compressive strength over time ${ }^{18,29}$, since water absorption and the content of poliHEMA cause plasticity in the material ${ }^{2}$. The data of the present study and the literature available ${ }^{1,15}$, however do not suggest a significant influence of storage on the compressive strength of Vitremer. In contrast, an increase in the compressive strength of Fuji II LC at a $P / L$ ratio of 1:3 (28 days) was observed, possibly due to the acid base reaction producing a stronger polysalt matrix. Vitremer demonstrates an improved integration of matrix and particles than Fuji II LC, consequently, with less voids ${ }^{27}$ and probably less water sorption and degradation of matrix. Furthermore, storage time did not significantly affect the properties of Vitremer.

The acid-base reaction has been extensively documented and it reinforces the hardness of the polymeric network ${ }^{5,25}$, but does not necessarily improve the mechanical strength $^{11,13}$. Considering the presence of two matrixes integrated by liquid structure, the maximum value may represent the highest strength, and not of the whole structure, which may be damaged by failure in their integration. Thus, variations in mechanical strength of glass ionomer cements under storage times are related to an

TABLE 2- Mean compressive strength (MPa) of Fuji II LC for three different $P / L$ ratios and storage times

\section{STORAGE TIME}

\begin{tabular}{|c|c|c|c|c|c|}
\hline \multirow[b]{2}{*}{24 hours } & \multicolumn{2}{|l|}{$3.2(1: 1)$} & \multicolumn{2}{|l|}{$1.6(1: 2)$} & $1.06(1: 3)$ \\
\hline & $183.88 \pm 18.34$ & A, a & $129.76 \pm 9.33$ & $\mathrm{~B}, \mathrm{a}$ & $95.54 \pm 7.51 \quad c, b$ \\
\hline 7 days & $212.36 \pm 43.33$ & $A, a$ & $146.41 \pm 16.27$ & $\mathrm{~B}, \mathrm{a}$ & $67.61 \pm 5.46 \quad c, b$ \\
\hline 28 days & $193.18 \pm 18.15$ & A, a & $148.66 \pm 4.39$ & $\mathrm{~B}, \mathrm{a}$ & $133.74 \pm 9.17 \quad \mathrm{~B}, \mathrm{a}$ \\
\hline
\end{tabular}

Means followed by the same small case letters in the column and capital letters in the row indicate no statistical difference at the 95\% confidence level (Tukey's test, $p>0.05$ ). 
equilibrium of factors that increase strength, such as hydration of metal-carboxylate links and maturation of the polysalt matrix, and other factors that decrease them, such as polymer matrix hydrolysis, which occurs at different times and explains the importance of water sorption in the aging process $^{7,9}$

\section{CONCLUSION}

Compressive strength of resin-modified glass ionomer cements Fuji II LC and Vitremer was reduced when powder/ liquid ratio was reduced from 1:1 to 1:2 and 1:3.

Storage in water for 24 hours, 7 days and 28 days had little influence on compressive strength of Fuji II LC and Vitermer. Only Fuji II LC at 1:3 P/L ratio was affected with an increase in strength after 28 days of storage.

\section{ACKNOWLEDGEMENTS}

The authors would like to thank CNPq for financial support for this project. They also express their thanks to Suarez Import Co. for providing the Fuji Coat LC.

\section{REFERENCES}

1- Akashi A, Matsuya Y, Unemori M, Akamine A. The relationship between water absoption characteristics and the mechanical strength of resin-modified glass-ionomer cements in long- term water storage. Biomaterials. 1999;20:1573-8.

2- Anstice HM, Nicholson JW. Studies on structure of ligth-cured glass-ionomer cements. J Mater Sci Mater Med. 1992;3:447-51.

3- Attin T, Vataschki M, Hellwig E. Properties of resin-modified glass-ionomer restorative materials and two polyacid-modified resin composite materials. Quintessence Int. 1996;27:203-9.

4- Billington RW, Williams JA, Pearson GJ. Variation in powder/ liquid ratio of a restorative glass-ionomer cement used in dental practice. Br Dent J. 1990;169:164-7.

5- Burke FM, Hamlin PD, Lynch EJ. Depth of cure of ligth-cured glass-ionomer cements. Quintessence Int. 1990;21:977-81.

6- Cattani-Lorente MA, Godin C, Meyer JM. Early strength of glass ionomer cements. Dent Mater. 1993;9:57-62.

7- Cattani-Lorente MA, Godin C, Meyer JM. Mechanical behavior of glass-ionomer cements affected by long-term storage in water. Dent Mater. 1994;10:37-44.

8- Cattani- Lorente MA, Dupuis V, Moya F, Payan JM, Meyer JM. Comparative study of the physical properties of a polyacid- modified composite resin and a resin- modified glass ionomer cement. Dent Mater. 1999;15:21-32.

9- Drummond JL, Lenke JW, Randolph RG. Compressive strength comparison and crystal morphology of dental cements. Dent Mater. $1988 ; 4: 38-40$

10 - Flório FM, Pereira AC, Meneghim MC, Ramacciato JC. Evaluation of non-invasive treatment applied to occlusal surfaces. ASCD J Dent Child. 2001;68:326-31.
11- Hegarty AM, Pearson GJ. Erosion and compressive strength of hybrid glass-ionomer cements when ligth-activated or chemically set. Biomaterials. 1992;14:349-52.

12 - International Standards Organization. ISO standard 9917. Filling and restorative materials. Geneva Switzerland ISO Copyrigth Office; 2000

13- Kerby RE, Knobloch L, Thakur A. Strength properties of visiblelight-cured resin-modified glass-ionomer cements. Oper Dent. 1997;22:79-83.

14- Luca-Fraga L, Pimenta LAF. Clinical evaluaton of glass-ionomer/ resin-based hybrid materials used as pit and fissure sealants. Quintessence Int. 2001;32:463-8.

15- Mc Carthy MF, Hondrum SO. Mechanical and bond strength properties of light-cured and chemically cured glass ionomer cements. Am J Orthod Dentofacial Orthop. 1994;105:135-41.

16- Mèjare I, Mjör IA. Glass ionomer and resin-based fissure sealants: a clinical study. Scand J Dent Res. 1990;98:345-50.

17- Mitsuhashi A, Hanaoka K, Teranaka T. Fracture toughness of resin modified glass-ionomer restorative materials: effect of powder/ liquid ratio and powder particle size reduction on fracture toughness. Dent Mater. 2003;19:747-57.

18- Nicholson JW, Anstice HM, Mc Lean JW. A preliminary report on the effect of storage in water on the properties of commercial light-cured glass-ionomer cement. Br Dent J. 1992;173:98-101.

19- Pereira AC, Basting RT, Pinelli C, Meneghim MC, Werner CW. Retention and caries prevention of Vitremer and Ketac-Bond used as occlusal sealants. Am J Dent. 1999;12:62-4.

20- Pereira AC, Pardi V, Basting RT, Menighin MC, Pinelli C, Ambrosano GMB, et al. Clinical evaluation of glass ionomers used as fissure sealants: twenty-four-months results. ASDC J Dent Child. 2001;68:168-74

21- Piwowarczyk A, Lauer HC. Mechanical Properties of luting cements after storage. Oper Dent. 2003;28:535-42.

22- Prosser HJ, Powis DR, Brant P, Wilson AD. Characterization of glass-ionomer cements. 7. The physical properties of current materials. J Dent. 1984;12:231-40.

23- Quackenbush BM, Donly KJ, Croll TP. Solubility of a resinmodified glass-ionomer cement. ASDC J Dent Child. 1998;65:310-2.

24- Smales RJ, Lee YK, Lo FW, Tse CC, Chung MS. Handling and clinical performance of a glass ionomer sealant. Am Dent J. 1996;9:203-5.

25- Swift Jr EJ, Pawlus MA, Vargas MA, Fortin D. Depth of cure of resin-modified glass ionomers. Dent Mater. 1995;11:196-200.

26- Weerheijm KL, Kreulen CM, Gruythuysen RMJ. Comparison of retentive qualities of two glass-ionomer cements used as fissure selants. ASDC J Dent Child. 1996;63:265-7.

27- Xie D, Brantley WA, Culbertson BM, Wang G. Mechanical properties and microstructures of glass-ionomer cements. Dent Mater. 2000;16:129-38

28- Xu X, Burgess JO. Compressive strength, fluoride release and recharge of fluoride-releasing materials. Biomaterials. 2003;24:245161.

29- Yap AUJ, Mudambi S, Chew CL, Neo JCL. Mechanical properties of an improved visible ligth-cured resin-modified glass ionomer cement. Oper Dent. 2001;26:295-301. 